\title{
Knowledge and attitude towards contraceptive methods for spacing and decision making factors regarding its use in postpartum women
}

\author{
Jyotsna Sharma $^{1}$, Gowri Dorairajan ${ }^{2}$, Palanivel Chinnakali ${ }^{3}$
}

${ }^{1}$ Final Year Medical Student, JIPMER, Puducherry-605006, India
2 Department of Obstetrics \& Gynaecology, JIPMER, Puducherry-605006, India
${ }^{3}$ Department of Preventive and Social Medicine, JIPMER, Puducherry-605006, India

Received: 06 April 2015

Accepted: 09 May 2015

\section{*Correspondence:}

Dr. Gowri Dorairajan,

E-mail: gowridorai@ hotmail.com

Copyright: () the author(s), publisher and licensee Medip Academy. This is an open-access article distributed under the terms of the Creative Commons Attribution Non-Commercial License, which permits unrestricted non-commercial use, distribution, and reproduction in any medium, provided the original work is properly cited.

\begin{abstract}
Background: Though the permanent methods have been successful in our country the spacing methods lag behind and unwanted unplanned pregnancies continue to be high. This study was undertaken to explore the knowledge level, attitude and the factors influencing the potential use of spacing contraception among recently delivered women.

Methods: This cross sectional study was carried out in a teaching institution using a structured questionnaire among recently delivered women willing to participate in the study.

Results: Among the 404 women studied $74 \%$ were primipara. The level of awareness about spacing contraception was $70 \%$ though only $30 \%$ knew the correct use. The most frequent source of information was social circle and friends. Two thirds of women felt the need for spacing but $65.8 \%$ were not willing to adopt any modern method for fear of side effects and want of husband approval. Bivariate analysis showed that prenatal counselling $\left(X^{2}=41.33\right.$ $\mathrm{P}<0.001)$ and higher education $\left(\mathrm{X}^{2}=16.6 \mathrm{P}<0.001\right)$ were significant predictors of knowledge about spacing contraception. On bivariate analysis prenatal counselling $\left(\mathrm{X}^{2}=3.83 \mathrm{p}<0.05\right)$ and prior discussion with husbands $\left(\mathrm{X}^{2}=17.4 \mathrm{P}=0.001\right)$ emerged to be the most significant predictors of positive attitude towards contraception. On multivariate analysis prior discussion with husband emerged as the most significant factor to predict the likely use of contraception for spacing (Adjusted OR-2.8; 95\%CI 1.6-5.1).

Conclusions: Prenatal counselling detailing about the contraceptive methods and doing away with the myths and involving husbands in these sessions would be important strategies to improve the effective use of spacing contraception among recently delivered women.
\end{abstract}

Keywords: Spacing, Contraception, Knowledge, Attitude, Counselling, Postpartum

\section{INTRODUCTION}

The family planning program in our country has been in place for more than four decades. The permanent methods and limiting the family size has been successful but contraception for spacing is lagging behind. Utilization of spacing method of contraception varied from $13.8 \%$ in a study done in north India $^{1}$ to $26 \%$ in a study on more than 1 lakh women across 28 districts. $^{2}$
Regardless of the education $75 \%$ of women were found to be sexually active by 3 months after delivery. ${ }^{3}$ In a study conducted on 272 postpartum women attending a private medical college in Lucknow, a city in Uttar Pradesh, India, 28\% women were sexually active within 6 weeks postpartum and only $54.4 \%$ used contraception the most common being condoms. ${ }^{4}$

In a study done in Bangladesh $^{5}$ that examined the understanding and preferences of postpartum 
contraception, the authors found that women perceive that modern methods of contraception are "strong" and potentially damaging to their own and their new-born's health and majority of women are reluctant to adopt family planning methods soon after birth, particularly during postpartum amenorrhoea. Thus the reasons for poor rates of spacing methods of contraception need to be urgently explored. This study is undertaken to assess the knowledge, attitude of women and the factors affecting decision making regarding spacing contraception among women who deliver in our hospital.

\section{METHODS}

This descriptive cross sectional study was undertaken in the post natal wards and clinics of our hospital (a tertiary care centre) using a structured questionnaire either selfadministered or through interview method. The selfadministered questionnaire was converted to local language and both linguistic and content validation was done. It was convenience sampling.

The domains of questionnaire included demographic data like age, income, education and occupation of both the partners, parity etc., data on awareness about the various methods of contraception, their source of information, the attitude of women towards use of spacing methods of contraception in terms of proportion of women feeling its need, any negative attitude towards the methods, any myths towards the methods and the decision making factors including counselling during pregnancy or after delivery by health workers, number of earning members, the deciding member for these matters.

The women aware of at least one spacing method including its correct usage were considered knowledgeable.

Women recently delivered with their babies roomed in were included in the study after obtaining informed consent. Women where the pregnancy outcome was still births or neonatal death, women with postpartum complications, women who have undergone postpartum sterilization or are subjecting themselves to sterilization operation were excluded.

Sample size: Assuming alpha error as 5\% and absolute precision of $5 \%$, knowledge regarding spacing method as $50 \%,{ }^{2} 400$ recently delivered women were required for the study and assuming alpha error as $5 \%$ and absolute precision of $5 \%$, use spacing method as $26 \%,{ }^{2} 174$ recently delivered women were required for the study. So the higher number of 400 was chosen.

Data processing and analysis was done using SPSS software package. Statistical analysis: Mean \pm SD and median (IQR) was calculated for the quantitative data like age. The proportion of women aware and knowledgeable about spacing methods of contraception was calculated. Bivariate and multivariate regression analysis was done to look at the factors affecting knowledge and attitude and the likely use.

\section{RESULTS}

404 women consented and finally completed the study. In our study the mean age was found to be 23.86 years. The age ranged from 18-39 years. There were 13 (3.2\%) teenage pregnancies. $40.8 \%$ of the husbands were skilled workers. Other demographic data is shown in Table 1.

Table 1: Salient demographic details of the study population.

\begin{tabular}{|c|c|}
\hline Demographic details & $\begin{array}{l}\text { Percentage of women } \\
\text { studied }\end{array}$ \\
\hline Education - ( $\geq$ Middle school) & $\begin{array}{l}\text { Women - 58\%; } \\
\text { Husbands - 57\% }\end{array}$ \\
\hline Below poverty line women & $48 \%$ \\
\hline Primipara & $74 \%$ \\
\hline Occupation of women & $88 \%$ housewives \\
\hline Unplanned pregnancy & $\begin{array}{l}11 \% \text { in primigravida, } \\
22 \% \text { in second }\end{array}$ \\
\hline
\end{tabular}

$382(94.6 \%)$ women had never used any contraceptives earlier. $283(70 \%)$ were aware of at least one contraceptive for spacing however only $32.3 \%$ of them were sure about its correct use. The level of awareness was maximum for the intrauterine contraceptive devices (48.5\%). Only $2.1 \%$ were aware about progesterone injections as a method of spacing during lactation.

$49.3 \%$ were not sure where to get these contraceptives from.

The source of information about contraception in the women studied is shown in Figure 1. The most popular was through social circle and friends.

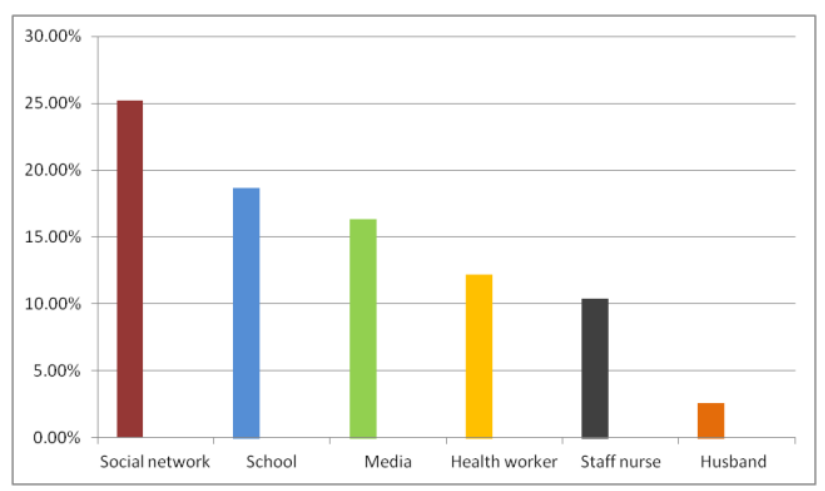

Figure 1: Source of information about the contraceptive methods of spacing.

Among the 404 women only 44 women (11\%) had been counselled by health counsellors during the antenatal period about contraception. $89 \%$ women did not receive any counselling during prenatal period. 
Bivariate analysis (Table 2) showed that prenatal counselling $\left(\mathrm{X}^{2}=41.33 \mathrm{P}<0.001\right)$ and higher education $\left(\mathrm{X}^{2}=16.6 \quad \mathrm{P}<0.001\right)$ were significant predictors of knowledge about spacing contraception.

Table 2: Logistic regression showing factors affecting willingness to adopt contraception.

\begin{tabular}{|llll|}
\hline $\begin{array}{l}\text { Factors } \\
\text { Knowledge } \\
\text { about contraception } \\
\text { Yes } \\
\text { No }\end{array}$ & 0.9 & $0.5-1.5$ & 0.698 \\
\hline $\begin{array}{l}\text { Family support } \\
\text { Yes }\end{array}$ & 2.4 & $\begin{array}{l}\text { 95\% Conf. } \\
\text { Interval }\end{array}$ & $\begin{array}{l}\text { P } \\
\text { value }\end{array}$ \\
No & $4.8-11.6$ & 0.290 \\
\hline $\begin{array}{l}\text { Felt spacing 3 years } \\
\text { or more }\end{array}$ & & & \\
$\begin{array}{l}\text { Yes } \\
\text { No }\end{array}$ & 1.1 & $0.7-1.9$ & 0.645 \\
\hline $\begin{array}{l}\text { Prenatal counselling } \\
\text { Yes }\end{array}$ & & $0.8-3.5$ & 0.198 \\
No & 1.7 & & \\
\hline $\begin{array}{l}\text { Discussion with } \\
\text { husband }\end{array}$ & & $1.6-5.1$ & $\mathbf{0 . 0 0 2 *}$ \\
$\begin{array}{l}\text { Yes } \\
\text { No }\end{array}$ & 2.8 & $0.7-1.9$ & 0.527 \\
\hline $\begin{array}{l}\text { Beyond school } \\
\text { education } \\
\text { Yes } \\
\text { No }\end{array}$ & & & \\
\hline
\end{tabular}

$* \mathrm{P}<0.05$, Significant

Regarding attitude 261 women (64.6\%) felt the need for spacing of 2 or 3 years between pregnancies. However $266(65.8 \%)$ were not willing to adopt any method even when taught about it. $114(28.2 \%)$ were willing to adopt a modern method. 24 (6\%) women were not sure.

The reasons for the negative attitude are shown in Figure 2. It is important to note that fear of side effects was the most frequent and $16 \%$ of the woman felt that hindrances from the husband and family is the reason for nonwillingness to adopt any contraceptive method.

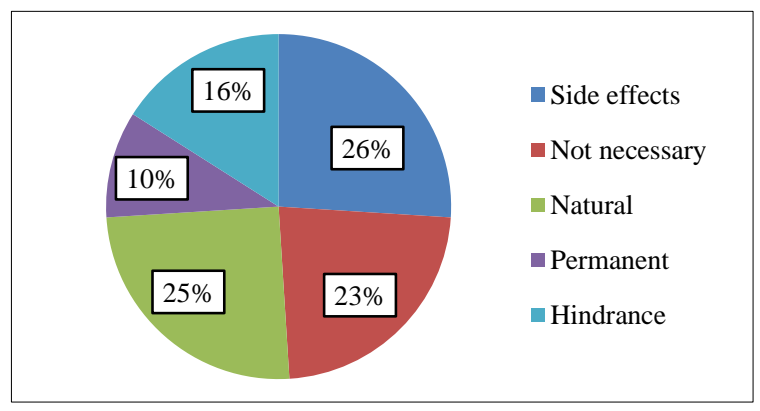

Figure 2: The reasons for negative attitude for modern contraceptive methods.
The decision regarding the family size is mutual in 228 $(56.4 \%)$, by the woman herself in $83(20.5 \%)$ cases. In another $20.5 \%$, this decision is with the husband and the mother in law and in $2.6 \%$ cases, other family members make this decision. We observed that in $83.4 \%$ there were no healthy discussions about contraception in the family members.

On bivariate analysis prenatal counselling $\left(\mathrm{X}^{2}=3.83\right.$ $\mathrm{P}<0.05)$ and prior discussion with husbands $(\mathrm{X} 2=17.4$ $\mathrm{P}=0.001)$ emerged to be the most significant predictors of positive attitude towards contraception.

On multivariate analysis (Table 2), prior discussion with husband emerged as the most significant factor to predict the likely use of contraception for spacing.

\section{DISCUSSION}

In our study $70 \%$ women were aware of at least one method of contraception though only $30 \%$ had knowledge about the correct use. A similar level of awareness was reported by Mathe et al; ${ }^{6}$ in their study on study on 572 post-partum women. This is in contrast to the National Family Health Survey $3^{7}$ which found a nearly universal knowledge about contraception but the usage was only $56 \%$. However this survey had included all women from 15-45 years (rural as well as urban).

In our study the pregnancy was unplanned in $11 \%$ of the primigravida and $95(22 \%)$ of the second gravida. Unplanned pregnancy rate varied from $8 \%$ in a study on 3551 women from four cities in India $^{8}$ to $39 \%$ in the study by Bastianelli and colleagues ${ }^{9}$ on 436 recently delivered women.

In our study the higher education status of the women and prenatal counselling were significant predictors of higher level of knowledge about spacing contraception.

Association of higher education status with knowledge of spacing contraception has been observed by other authors in their studies. ${ }^{3,10,11}$ Some authors have observed that the decision for use was also significantly affected by the women's level of education. 3,12,13

In our study only $11 \%$ had received prenatal counselling on spacing contraception. In the study by Bastianelli and colleagues ${ }^{9}$ also only $5.5 \%$ of the 436 women had acknowledged receiving information about contraception in the antenatal period. Prenatal counselling has been found to be crucial in improving the use of contraception. $^{10,14}$ Barber $^{15}$ observed an OR of 2.2 for modern contraceptive use after pre natal counselling which increased to a high O.R of 5.2 for IUD use. In the Meta analysis of six studies, the Cochrane data group ${ }^{16}$ found that intervention with educational strategies are associated with significantly higher use of modern methods of contraception. 
In our study we observed that the most popular source of information for contraception was social network of friends, neighbors and relatives. Only $55(16.3 \%)$ heard it through media. This is not withstanding that $58.4 \%$ of our women had middle or high school education. It is possible in spite of scholastic education in our study group, social network was important, probably because of less emphasis on sex education and contraception in school curriculum a decade ago. In contrast, media was found to be the most common source of information by other authors. ${ }^{11,17}$

In our study even after receiving adequate knowledge, only $113(28.2 \%)$ was willing to adopt a method of contraception. $266(65.8 \%)$ was not willing to adopt a method. Fear of side effects was perceived by $26 \%$ of those having negative attitude for modern contraception. In another $16 \%$, the want of family/ husband approval was a factor. Similar reasons for negative attitude have been reported by other authors. ${ }^{18,19}$ In our study $23 \%$ thought that it is not necessary as they have a low risk of pregnancy.

In a study by Bhattathiry and Ethirajan ${ }^{20}$ who studied 700 married couples in Tamil Nadu also, about $18 \%$ perceived the risk of pregnancy to be low. In the study by Bastianelli and colleagues ${ }^{9} 50 \%$ of those who did not use postpartum contraception also had felt that they don't need it.

However while analysing the willingness to adopt contraception, multivariate analysis in our study, revealed prior discussion and concurrence with husband to be the most important factor. Partner related variables were observed as important factor for contraceptive use by Brunie and colleagues. $^{21}$

Yadav and colleagues ${ }^{22}$ studied 200 couples and reported that $6.5 \%$ women were not free to use contraception without husband's consent. Husband opposition was found to be an important hindrance in the study by Mathe et al. Husband concurrence and approval was found to have a significant effect on the adoption of family planning methods by other authors also. ${ }^{23,24}$

Thus we conclude that in our study population the high level of awareness needs to be translated to knowledge by proper and detailed counselling. Higher education status and prenatal counselling are significant predictors of higher knowledge. The need for spacing is felt by more than two thirds of recently delivered women. The myths about the contraceptive methods is an important reason for negative attitude and husband approval turned out to be the single most important factor predicting potential use.

Prenatal counselling detailing about the methods and doing away with the myths and involving husbands in these sessions would be important strategies to improve the effective use of spacing contraception among recently delivered women.

\section{ACKNOWLEDGEMENTS}

This study was carried under the Short Term Student (STS) scheme of Indian Council of medical Research (ICMR). The project report has been accepted and approved by ICMR.

Funding: No funding sources

Conflict of interest: None declared

Ethical approval: The study was approved by the institutional ethics committee

\section{REFERENCES}

1. Mahmood SE, Srivastava A, Shrotriya VP, Shaifali I, Mishra P. Postpartum contraceptive use in rural Bareilly. Indian J Comm Health. 2011;23(2):56-7.

2. Chandhick N, Dhillon BS, Kambo I, Saxena NC. Contraceptive knowledge, practices and utilization of services in the rural areas of India (an ICMR task force study). Indian JMed Sci. 2003;57(7):303-10.

3. Kanojia JK, Nirbhavane NC, Toddywala VS, Betrabet SS, Patel SB, Datte S, et al. Dynamics of contraceptive practice amongst urban Indian women. Natl Med J India. 1996;9(3):109-12.

4. Kunwar S, Faridi MMA, Singh S, Zahra F, Alizaidi Z. Pattern and determinants of breastfeeding and contraceptive practices among mothers within six months postpartum. Biosci Trends. 2010;4(4):186-9.

5. Salway S, Nurani S. Uptake of contraception during postpartum amenorrhoea: understandings and preferences of poor, urban women in Bangladesh. Soc Sci Med. 1998;47(7):899-909.

6. Mathe JK, Kasonia KK, Maliro AK. Barriers to adoption of family planning amongwomen in Eastern Democratic Republic of Congo. Afr J Reprod Health. 2011;15(1):69-77.

7. International Institute for Population Sciences (IIPS) and Macro International. National family health survey (NFHS-3), 2005-06: India. In: IIPS, eds. IIPS Survey. Volume I. Chap 5. Mumbai: IIPS; 2007: 111-113.

8. Speizer IS, Calhoun LM, Hoke T, Sengupta R. Measurement of unmet need for family planning: longitudinal analysis of the impact of fertility desires on subsequent childbearing behaviours among urban women from Uttar Pradesh, India. Contraception. 2013;88(4):553-60.

9. Bastianelli C, Farris M, Benagiano G, D'Andrea G. Unmet needs and knowledge of postpartum contraception in Italian women. Clin Exp Obstet Gynecol. 2013;40(4):514-8.

10. Hernandez LE, Sappenfield WM, Goodman D, Pooler J. Is effective contraceptive useconceived prenatally in Florida? The association between prenatal contraceptive counseling and postpartum contraceptive use. Matern Child Health J. 2012;16(2):423-9.

11. Hayat H, Khan PS, Imtiyaz B, Hayat G, Hayat R. Knowledge, attitude and practice of contraception in 
rural Kashmir. J Obstet Gynaecol India. 2013;63(6):410-4.

12. Romero-Gutiérrez G, Garcia-Vazquez MG, HuertaVargas LF, Ponce-Ponce de Leon AL. Postpartum contraception in LeÓn, Mexico: a multivariate analysis. Eur J Contracept Reprod Health Care. 2003;8(4):210-6.

13. Di Giacomo P, Sbarlati A, Bagnasco A, Sasso L. Woman's contraceptive needs and preferences in the postpartum period: an Italian study. J Clin Nurs. 2013;22(23-24):3406-17.

14. Sebastian MP, Khan ME, Kumari K, Idnani R. Increasing postpartum contraception in rural India: evaluation of a community-based behavior change communication intervention. Int Perspect Sex Reprod Health. 2012;38(2):68-77.

15. Barber SL. Family planning advice and postpartum contraceptive use among low-income women in Mexico. Int Fam Plan Perspect. 2007;33(1):6-12.

16. Lopez LM, Grey TW, Chen M, Hiller JE. Strategies for improving postpartum contraceptive use: evidence from non-randomized studies. Cochrane Database Syst Rev. 2014;11:CD011298.

17. Mustafa R, Afreen U, Hashmi HA. Contraceptive knowledge, attitude and practice among rural women. J Coll Physicians Surg Pak. 2008;18(9):5425.

18. Gebremariam A. Intention to use long acting and permanent contraceptive methods and factors affecting it among married women in Adigrat town, Tigray, Northern Ethiopia. Reprod Health. 2014;11:24.
19. Saroha E, Altarac M, Sibley LM. Low use of contraceptives among rural women in Maitha, Uttar Pradesh, India. J Indian Med Assoc. 2013;111(5):302-6, 308.

20. Bhattathiry MM, Ethirajan N. Unmet need for family planning among married women of reproductive age group in urban Tamil Nadu. J Fam Community Med. 2014;21(1):53-7.

21. Brunie A1, Tolley EE, Ngabo F, Wesson J, Chen M. Getting to $70 \%$ : barriers to modern contraceptive use for women in Rwanda. Int $\mathbf{J}$ Gynaecol Obstet. 2013;123(Suppl 1):e11-5.

22. Kapil Yadav, Bir Singh, Kiran Goswami. Agreement and concordance regarding reproductive intentions and contraception between husbands and wives in Rural Ballabgarh, India. Indian J Community Med. 2010;35(1):19-23.

23. Bhattarai D, Panta OB. Knowledge attitude and practice on contraception in village women in Khotang. J Nepal Health Res Counc. 2013;11(23):40-3.

24. Eliason S, Baiden F, Quansah-Asare G, GrahamHayfron Y, Bonsu D, Phillips J, et al. Factors influencing the intention of women in rural Ghana to adopt postpartum family planning. Reprod Health. 2013;10:34.

DOI: $10.18203 / 2320-1770 . i j r \operatorname{cog} 20150086$

Cite this article as: Sharma J, Dorairajan G, Chinnakali

P. Knowledge and attitude towards contraceptive methods for spacing and decision making factors regarding its use in postpartum women. Int J Reprod Contracept Obstet Gynecol 2015;4:750-4. 